\title{
$1 \quad$ An efficient gene excision system in maize
}

2 Ning Wang ${ }^{1}$, Maren Arling ${ }^{1}$, George Hoerster ${ }^{1}$, Larisa Ryan ${ }^{1}$, Emily Wu ${ }^{1}$, Keith Lowe ${ }^{1}$, Bill

3 Gordon-Kamm ${ }^{1}$, Todd J. Jones ${ }^{1}$, Nicholas Doane Chilcoat ${ }^{1}$ and Ajith Anand ${ }^{1}$

$4 \quad{ }^{1}$ Corteva Agriscience, Johnston, IA USA

5

$6 \quad$ ning.wang@,corteva.com

$7 \quad$ maren.arling@,corteva.com

$8 \quad$ george.hoerster@corteva.com

9 larisa.ryan@,corteva.com

10 emily.wu@corteva.com

11 keith.lowe@corteva.com

12 william.gordon-kamm@,corteva.com

13 todd.j.jones@,corteva.com

14 doane.chilcoat@,corteva.com

$15 *$ Corresponding author: ajith.anand@corteva.com

\section{Keywords;}

17 Agrobacterium; developmentally-regulated promoters; heat-shock promoters; morphogenic

18 genes; marker-free events; rapid maize transformation

\section{Abbreviations;}

20 Bbm: Babyboom, Cre: CRE recombinase, HSP: Heat-shock promoters, SMG: Selectable marker-

21 free; Pro: promoters, QE: Quality events, UE: Usable event; Wus2; Wuschel2

22 


\section{ABSTRACT}

2 Use of the morphogenic genes Baby Boom (Bbm) and Wuschel2 (Wus2), along with new ternary

3 constructs, has increased the genotype range and the type of explants that can be used for maize

4 transformation. In addition, altering the ectopic expression pattern for $B b m / W u s 2$ has resulted in

5 rapid maize transformation methods that are faster and applicable to a broader range of inbreds.

6 However, expression of $\mathrm{Bbm} / \mathrm{Wus} 2$ can compromise the quality of regenerated plants, leading to

7 sterility. We reasoned excising morphogenic genes after transformation but before regeneration

8 would increase production of fertile T0 plants. We developed a method that uses an inducible

9 site-specific recombinase $(\mathrm{Cre})$ to excise morphogenic genes. The use of developmentally

10 regulated promoters, such as Ole, Glb1, End2 and Ltp2, to drive Cre enabled excision of

11 morphogenic genes in early embryo development and produced excised events at a rate of $25 \%$ -

$12 \quad 100 \%$. A different strategy utilizing an excision-activated selectable marker produced excised

13 events at a rate of $53.3 \%-68.4 \%$; however, the transformation frequency was lower $(12.9 \%$ -

$1449.9 \%$ ). The use of inducible heat shock promoters (e.g. Hsp 17.7, Hsp26) to express Cre, along

15 with improvements in tissue culture conditions and construct design, resulted in high frequencies

16 of T0 transformation (29\%-69\%), excision (50\%-97\%), usable quality events $(3.6 \%-14 \%)$, and

17 few escapes (non-transgenic; 14\%-17\%) in three elite maize inbreds. Transgenic events produced

18 by this method are free of morphogenic and marker genes. 


\section{INTRODUCTION}

The use of the morphogenic genes $B b m$ and $W u s 2$ has considerably increased transformation frequencies and reduced genotype dependence in many cereal crops (Lowe et al., 2016;Mookkan et al., 2017;Anand et al., 2018;Lowe et al., 2018). This enabled the development of a rapid transformation method involving direct formation of somatic embryos and T0 plants from immature scutella (Lowe et al., 2018). This approach has facilitated transformation (Lowe et., 2016; Mookkan et al.,2017) and CRISPR/Cas-mediated editing (Chilcoat et al., 2017) in numerous elite maize inbreds, and enabled use of alternate explants, such as embryo slices from mature seeds or leaf segments, for successful maize transformation (Lowe et al., 2016; Lowe et al., 2018). However, ectopic expression of the morphogenic genes often resulted in pleiotropic effects including abnormal shoots/roots and infertile plants (Lowe et al., 2016). The use of promoters that drive high expression levels during the transformation process, but lower expression levels in the vegetative plant, provides one option to ameliorate these problems (Lowe etal.,2018) but the presence of morphogenic genes can still result in some negative effects and is undesirable in commercial products. While fertile T0 plants can be recovered under these conditions, non-visible pleiotropic effects remain a distinct possibility. Similarly, transgenic plants regenerated through de novo meristem induction stimulated by morphogenic gene expression also resulted in developmental abnormalities (Maher et al., 2020), and without removal also raise concerns that non-visible pleiotropic effects are possible. Therefore, excising the morphogenic genes is desirable for regenerating healthy plants, for transgene testing and commercial product development. Previously a method using a non-integrating Wus2 gene expression approach recovered fertile T0 plants free-off morphogenic genes, however this method needed a plant selectable marker gene (SMG) for regenerating events (Hoerster et al., 
1 2020). Here we report an approach that allows excision of both the morphogenic gene and the

2 SMG used in transformation at the same time. As an added benefit this method eliminates any

3 adverse effect from the non-trait genes in commercial products.

4 Different strategies have been developed for the removal of helper genes following plant

5 transformation, often focused on removing plant selectable markers. One approach is co-

6 transformation with two constructs, one with the SMG and one with the gene of interest. In a

7 transgenic plant with independent insertions of each of these constructs, the selectable marker

8 can be segregated genetically (Hare and Chua, 2002;Puchta, 2003;Darbani et al., 2007;Ling et

9 al., 2016). Alternatively, SMGs can be removed by excision via homologous recombination

10 (Puchta, 2000;Zubko et al., 2000), elimination by transposition (Maeser and Kahmann, 1991;Gao

11 et al., 2015) or, by the use of recombinases to excise unwanted DNA. Several recombination

12 systems have been used to excise SMGs, including Cre/lox from bacteriophage P1 (Hoess et al.,

13 1982;Hoess and Abremski, 1985), Flp/frt from Saccharomyces cerevisiae (Cox, 1983;Senecoff

14 et al., 1985), R/RS from Zygosaccharomyces rouxii (Araki et al., 1985), and Gin/gix from

15 bacteriophage (Klippel et al., 1988). Recombinases have been delivered via retransformation

16 (Odell et al., 1990;Dale and Ow, 1991), sexual crosses (Bayley et al., 1992;Kilby et al.,

17 1995;Kerbach et al., 2005), or transient expression (Gleave et al., 1999;Kopertekh et al.,

18 2004;Kopertekh and Schiemann, 2005;Jia et al., 2006). In most of these systems excision takes

19 place after the T0 generation and requires screening multiple plants to find one that has

20 undergone successful excision. A design where the SMG and the recombinase genes are on the

21 same construct between the recombination sites has been referred to as "auto-excision"

22 (Verweire et al., 2007; Moravčíková et al., 2008), and allows generation of SMG-free events. By

23 placing the recombinase under the regulation of an inducible/chemical promoter, an expression 
1 system that allowed spatial and temporal control (regulated by external or intrinsic signals) was

2 shown to be faster and less resource-intensive (Chong-Pérez and Angenon, 2013; Yau and

3 Stewart, 2013).

4 We have evaluated three different strategies for auto-excision prior to regeneration to

5 recover stable T0 plants free of morphogenic genes and in some cases the SMG as well: 1) an

6 auto-excision system involving developmentally regulated promoters, 2) an excision-activated

7 marker gene system, and 3) an inducible promoter approach for excising both the morphogenic

8 genes and the SMG. The excision strategies were evaluated to meet key production

9 transformation criteria of 1) high transformation frequency, 2) high quality event (QE, single-

10 copy of T-DNA, backbone and morphogenic gene free) frequency, 3) ability to generate marker-

11 free T0 plants, and 4) applicability to multiple elite maize inbreds. The use of developmentally

12 regulated promoters driving Cre enabled auto-excision of morphogenic genes, but resulted in

13 low transformation frequency and QE recovery. These limitations were addressed using heat-

14 shock inducible promoters driving expression of $\mathrm{Cre}$, that resulted in higher frequencies of T0

15 transformation, gene-excision and QE recovery.

\section{Excision via developmentally-regulated promoters}

18 The presence of morphogenic genes in transgenic events is undesirable because of unpredictable

19 phenotypes (Lowe et al., 2016). Auto-excision of morphogenic genes occurs early in the

20 transformation process which enables trait evaluation in $\mathrm{T} 0$ generation and reduces attrition due

21 to T0 sterility. We evaluated several auto-excision designs, using Cre driven by various

22 promoters. These included seven different developmentally regulated (embryo or meristem)

23 promoters, the constitutive maize ubiquitin $(Z M-U b i)$ promoter, and the Agrobacterium nopaline 
1 synthase (Nos) promoter (Table 1). To facilitate excision, the morphogenic genes (Wus2 and

$2 \mathrm{Bbm}$ ) and the Cre gene cassette were flanked with a single pair of directly oriented loxP sites

3 (Figure $1 \mathrm{~A}$ ). The resulting excised events following auto excision is depicted in Figure 1B. We

4 evaluated two different inbreds (HC69 and PH2RT) to identify pro:Cre combinations that

5 produced high frequencies of both transformation and excision. Molecular event data is

6 presented in Table 2. All constructs tested produced stable transgenic events with some number

7 of properly excised events. The Ole pro: Cre had the highest transformation frequencies $(27.2 \%$ -

$8 \quad 37.1 \%)$, while the Glb1 pro:Cre construct produced events with higher QE frequencies (8.6\%-

$9 \quad 18.4 \%)$.

\section{Excision via marker gene activation}

12 Although we achieved auto-excision with all developmentally regulated promoters tested, even

13 for the best construct the usable events rate was around $2 \%$ and $80-90 \%$ of events were not

14 excised quality events. To improve efficiency, we designed constructs with SMG that was

15 activated only upon excision of the morphogenic genes. This approach selects directly for

16 excised events and was expected to increase QE frequency. A similar construct design was

17 previously used to optimize tissue culture conditions for recovering high quality maize

18 transgenic events (Chu et al., 2019). A schematic design of the construct is depicted in Figure 2A

19 and the quality excised product in Figure 2B. For these experiments, either the Glb1 or the Ole

20 promoters were used to drive $C r e$ expression for evaluation of excision-activated marker gene

21 selection. The data from side-by-side testing of these two promoters using the construct design

22 described in Figure 2 are summarized in Table 3. The construct containing Glb1 pro:Cre improved

23 T0 transformation and QE frequencies (1.8 and 1.4-fold), compared to the developmentally 
1 regulated gene-excision approach. When Ole pro:Cre was used, the T0 transformation frequency

2 was similar (>1.1-fold) while the QE frequency increased approximately 1.7-fold. The excision

3 frequency was higher when excision-activated selection was used, with excision frequencies of

$4 \quad 53.3 \%\left(\right.$ Ole $\left._{p r o}: \mathrm{Cre}\right)$ and $68.4 \%\left(\mathrm{Glb} b_{\text {pro }}\right.$ :Cre $)$ when compared to the previous approach.

5 Additionally, no null events (escapes) were identified by qPCR analysis.

The $G l b_{\text {pro: }}$ Cre construct design was further evaluated in two additional inbreds, PH84Z and PH85E, alongside HC69 for comparison (Table 4). QEs were recovered in all three inbreds,

8 which were free of the morphogenic genes with no escapes. Excision frequency was similar

9 (55\%-61\%) across all the inbreds; QE frequencies varied by genotype: $8.7 \%$ (HC69), 27.7\% (PH85E) and 6.7\% (PH84Z) leading to differences in usable quality event frequency (UE,

11 quality events per 100 embryos): 4.3\% (HC69), 3.6\% (PH85E) and 1.9\% (PH84Z).

\section{Excision via stress-inducible promoters}

14 To further improve efficiency, a series of stress-inducible promoters were tested for excision of morphogenic genes. The promoters were selected from a set of genes induced by heat (maize

16 Hsp17.7 and Hsp26) and drought (ZmRab17, SiRAB21, BdDRP1, and BdDRP12). The construct

17 design is identical to that described in Figure 1, where stress-inducible promoters drive Cre

18 expression as represented by pro:Cre. The different steps in the transformation process,

19 selection immature embryo infection, In preliminary screening, embryos derived from HC69

20 were infected with one of the six constructs and, subsequently subjected to one of three different

21 conditions: no heat shock (control), heat shock at $37^{\circ} \mathrm{C}$ for 1 day, or $42^{\circ} \mathrm{C}$ for $2 \mathrm{~h} /$ day for 3

22 consecutive days. The different steps in maize immature embryo transformation process,

23 included embryo infection with Agrobacterium strain continuing the construct (Figure 3A), 
1 selection of transgenic events on media supplemented with selectable marker (Figure 3B), heat-

2 shock treatment step (Figure 3C), regeneration of events on media with selection pressure

3 (Figure 3D) and rooting (Figure 3E), before the events were sent to greenhouse. The auto-

4 excision frequencies under induced and non-induced conditions were determined by qPCR

5 analysis. Somatic embryos on maturation media (18 dpi) with $0.1 \mathrm{mg} / \mathrm{L}$ imazapyr were subjected

6 to one of the heat conditions and moved onto a rooting media with $0.1 \mathrm{mg} / \mathrm{L}$ imazapyr following

7 heat shock (Figure 3D).

All promoters except Hsp26 were leaky under non-induced conditions, resulting in gene-

9 excision rates from $3.4 \%\left(\right.$ Rab1 $\left.7_{\text {pro }}\right)$ to $36 \%\left(B d R a b 21_{p r o}\right)$ compared to zero in the Cre-minus construct. For a subset of the promoters (Hsp1.7, Hsp26, Drp1 and Drp12), higher excision

11 frequencies ranging from $43 \%$ to $100 \%$, were observed in the $42^{\circ} \mathrm{C}, 2 \mathrm{~h} /$ day for 3 days heat

12 treatment. Longer exposure of the somatic embryos at $37^{\circ} \mathrm{C}$ adversely effected $\mathrm{T} 0$ event

13 recovery, compared to a short pulse of heat shock at $42^{\circ} \mathrm{C}(2 \mathrm{hr} /$ day for 3 days). Based on the

14 recovery of excised $\mathrm{T} 0$ events with $H s p 26_{\text {pro }}$ construct at $42^{\circ} \mathrm{C}$ treatment compared to $37^{\circ} \mathrm{C}$

15 treatment, this promoter appeared to be induced only at higher temperatures.

Additional experiments were performed to further evaluate gene excision and optimize

17 heat shock conditions using three of the inducible promoters (Hsp17.7, Hsp26 and Drp 12). HC69

18 embryos infected with the three constructs were subjected to heat shock treatment at the

19 maturation stage (Figure 3C). One of three different treatments were applied 1) no heat shock

20 (control), 2) $42^{\circ} \mathrm{C}$ for $2 \mathrm{~h}$ and 3$) 42^{\circ} \mathrm{C}, 2 \mathrm{~h}$ on 3 consecutive days to determine frequencies of

21 excision and UE recovery (Table 6). Consistent with the previous observation, Hsp 17.7pro

22 driving Cre expression under both heat treatments resulted in higher excision rates $(62.5 \%$ -

$2369.2 \%$ ) resulting in higher UE rates (10 to 18) compared to Hsp26 pro and Drp12 pro. Based on the 
1 data we identified Hsp17.7 pro as the preferred promoter for auto-excision with heat shock of

$242^{\circ} \mathrm{C}$ for $2 \mathrm{~h}$.

3

4 Optimization of heat-shock conditions to improve auto-excision

5 Further experiments were designed with $H_{s p 17.7}$ pro and Hsp26 $6_{\text {pro }}$ to optimize excision

6 conditions. After three weeks of selection, somatic embryos at the maturation stage (Figure 3)

7 were subjected to one of three different heat conditions 1) $42^{\circ} \mathrm{C}, 2 \mathrm{~h} /$ day for $2 \mathrm{~d}, 2$ ) $42^{\circ} \mathrm{C}$ for $24 \mathrm{~h}$,

8 or 3$) 45^{\circ} \mathrm{C}$ for $2 \mathrm{~h}$ /day to determine frequencies of excision and UE. Across the treatments,

9 transformation frequencies ranged from $35 \%-54.9 \%$, except in the $42^{\circ} \mathrm{C}$ for $24 \mathrm{~h}$ treatment of

10 embryos with Hsp17.7pro driving Cre expression, which was lower (Table 7). The heat

11 treatments increased excision rates, which varied with the conditions applied. Of the two Hsp

12 promoters tested, $H s p 17.7_{\text {pro }}$ resulted in events with higher excision frequency $\left(75 \%\right.$ at $42^{\circ} \mathrm{C}$ for

$1324 \mathrm{~h}$ and $76.6 \%$ at $45^{\circ} \mathrm{C}$ for $\left.2 \mathrm{~h}\right)$ compared to $H s p 26_{\text {pro }}(66.7 \%$ and $61.9 \%)$. The treatment, $45^{\circ} \mathrm{C}$

14 for $2 \mathrm{~h}$ worked best for both $H s p$ promoters.

15

16 Concurrent elimination of morphogenic and plant selectable marker genes

17 Next, we developed a strategy that simultaneously excised both the morphogenic genes and the

18 SMG. Two different SMGs, HRA and NPTII were tested. The construct design was slightly

19 changed to enable excision of the SMG by including it as part of the excised DNA (morphogenic

20 genes and Cre) flanked with a single pair of directly oriented loxP sites (Figure 4A) and the

21 resulting excised events are free of SMG (Figure 4B). The binary construct designs with

22 different selectable marker, morphogenic gene and a reporter gene $Z s-G R E E N$ is illustrated in

23 Figure 4A. Following transformation and selection (either $0.1 \mathrm{mg} / \mathrm{L}$ imazapyr for the $H R A$ gene 
1 or $150 \mathrm{mg} / \mathrm{L} \mathrm{G} 418$ for the $N P T I I$ gene), the somatic embryos were heat-shock treated at $45^{\circ} \mathrm{C}$ for

2 2h. Transformation data are presented in Table 8. Both HRA and NPTII constructs produced T0

3 plants free of morphogenic genes and SMG in the three inbreds tested. With the $H R A$ construct,

4 lower frequencies of QEs and UEs were observed and 2-fold more null events were produced

5 compared to the NPTII construct. The excision frequency was comparable in both $H R A$ and

6 NPTII constructs. Irrespective of the differences, both selectable markers produced high

7 frequencies of single copy, backbone-free events which are free of the morphogenic and marker

8 genes.

\section{Progeny analysis}

11 To study the inheritance and segregation of the morphogenic and SMG-free events, we screened

12 single-copy T0 plants free of morphogenic gene and SMG produced from the NPTII construct.

13 Thirteen T0 QE plants, six plants from HC69 and seven plants from PHR84Z, were selected for

14 progeny analysis. These plants were selected and self-pollinated in the greenhouse to enable

15 segregation analysis. Plants from all 13 events produced seeds, 100 to 200 seeds per plant. T1

16 plants were evaluated for zygosity using qPCR to evaluate copy number of Cre and NPTII genes

17 (excised DNA). Twelve of the 13 events showed the expected Mendelian inheritance of a single

18 copy T-DNA integration (1:2:1; chi-square $\mathrm{p}$-value $>0.05)$ in the $\mathrm{T} 1$ generation (Table 9).

\section{DISCUSSION}

21 In maize, direct induction of somatic embryos capable of rapidly germinating from immature

22 embryos (without a callus phase) has been demonstrated using the auxin-inducible promoter

23 Axigl driving Wus2 expression in combination with Bbm driven by a maize PLTP promoter 
1 (Lowe et al., 2018). Continued expression of morphogenic genes results in abnormal phenotypes

2 (Lowe et al., 2016). Therefore, removing morphogenic genes is imperative for accurate construct

3 evaluation and product development and, therefore, a prerequisite for broad application of the

4 technology. Morphogenic gene excision was accomplished using a drought-inducible Rab17

5 promoter driving Cre recombinase expression (Vilardell et al., 1991). Although this approach

6 was used for successful excision, the requirement for a desiccation step significantly reduced

7 stable event recovery and excision frequency (Lowe et al., 2016).

In order to develop a more efficient system promoters of seven developmentally

9 regulated genes, the Knotted-1 (Knl) (Bolduc et al., 2012), Leafy cotyledon 1 (Lec1) (Pelletier et

al., 2017), barley Lipid transfer protein2 (Ltp2) (Kalla et al., 1994), an early embryo response

11 gene (End2) (Casper et al., 2005), Globulin1 (Glb1) (Belanger and Kriz, 1991), and Olesin (Ole)

12 (Anand et al., 2017b) were evaluated for their ability to express Cre and excise morphogenic

13 genes. Glb1, Ole, and End2 promoters unlike inducible promoters did not need either physical or

14 chemical induction for auto-excision. While morphogenic gene removal was observed using

15 developmentally regulated promoters, this generally resulted in lower QE frequencies. A

16 possible explanation is that premature expression caused by early unintended low-level

17 expression from the developmentally regulated promoters resulted in low levels of Cre

18 expression.

Developing a method for regenerating events that are free of morphogenic genes using an

20 excision-activated marker gene system may increase excision frequency and QE recovery is

21 described (Chu et al., 2019). In a similar manner, developmentally regulated promoters Glb1

22 and Ole that are active during late embryo development (Kriz et al., 1990;Anand et al., 2017b),

23 were used to drive Cre expression for auto-excision. This strategy resulted in the reconstitution 
1 of the $H R A$ marker gene, which conferred herbicide resistance (Chu et al., 2019) and would grow

2 in the presence of selective agent. As anticipated, the strategy resulted in improved frequencies

3 of T0 transformation and QE that resulted in approximately a 2-fold increase in UE production.

4 Despite excision of the morphogenic genes and activation of selectable marker, a large

5 proportion of T0 events were multi-copy and non-excised. One possible explanation is the

6 dosage effect of the $H R A$ gene on rapid maize transformation, leading to enrichment of events

7 with stable insertions of more than one copy of the transgene. The other possibility is the

8 restricted activation of the developmental promoters leading to partial/incomplete excision,

9 which does not work in rapid maize transformation for enriching quality events.

To achieve controlled expression of recombinases genes for excision, inducible

11 promoters have been an attractive choice. These promoters predominantly fall into two

12 categories; 1) heat shock- or stress-inducible promoters (Kilby et al., 1995;Cuellar et al.,

13 2006;Zhang et al., 2006; Du et al., 2019) and, 2) chemical inducible promoters (Gatz, 1996;Zuo

14 and Chua, 2000). Expressing the recombinase under the control of promoters requiring inducers

15 (heat, osmotic, or chemical) has allowed tighter control of gene expression, while minimizing the

16 negative effect of ectopic gene expression. Among the stress-inducible promoters tested,

17 Hsp 17.7 pro and Hsp26 pro produced the best results for auto-excision based on a higher frequency

18 of T0 transformation, gene excision and UE rate. In maize, the regulation of $H s p$ promoters in

19 response to stresses has been described (Pegoraro et al., 2011), including accumulation of $H s p$

20 proteins under temperatures over $32-33^{\circ} \mathrm{C}$ (Ristic et al., 1991;Vierling, 1991) and enhanced

21 Hsp70 synthesis under drought and/or heat (Hu et al., 2010). The heat-inducible auto-excision

22 system was previously described using a construct design that involves $H s p 70_{\text {pro }}$ driving the Cre

23 recombinase for elimination of the SMG (egfp) while a second marker gene, expressing the 
1 anthocyanin pigmentation (Rsc) gene, was used for event sorting (Du et al., 2019). While

2 successful, the strategy has limited practical application requiring tracking of transgenes in the

3 T1 generation and subsequent segregation, which is resource-and time-intensive.

4 Taking a methodological approach, a system was developed to obtain morphogenic gene-

5 free events at high frequencies $(66 \%-77 \%$ of the total events generated). The overall strategy was

6 to develop an efficient auto-excision system for rapid maize transformation, with the objective of

7 eliminating both morphogenic and marker genes, that is highly efficient to meet the needs of

8 high throughput maize transformation. The method we developed resulted in the elimination of

9 morphogenic and marker genes at the maturation stage of transformation at high frequencies

10 (ranging from 60\%-97\%) in multiple elite inbreds. This was achieved by optimizing tissue

11 culture conditions, optimization of heat shock treatment and identifying a versatile SMG. The

12 stably transformed plants were normal, produced seeds and showed stable transmission of the

13 integrated T-DNA to the next generation.

MATERIALS AND METHODS

\section{Plant Material}

17 Pioneer temperate maize inbreds (R03, PH2RT, PH85E and PH84Z) were used in this study. All

18 plants used for source immature embryos were grown in the greenhouse. One of the inbred lines

19 (R03) is nonproprietary and publicly available. The other three inbred lines described here are

20 proprietary (PH2RT, PH85E and PH84Z). In order to protect Corteva Agriscience proprietary

21 germplasm, such germplasm will not be made available except at the discretion of Corteva

22 Agriscience and then only in accordance with all applicable governmental regulations. 


\section{Donor material and tissue culture}

2 Seeds were germinated and grown in a greenhouse at temperature set-points of $25.5 / 20.0^{\circ} \mathrm{C}$

3 (day/night), and 16-h daylight. After $21 \mathrm{~d}$, seedlings were transplanted into $5.9 \mathrm{~L}$ pots containing

4 a soil-less substrate composed of $38 \%$ Canadian sphagnum peat, $51 \%$ composted bark, $8 \%$

5 perlite, and 3\% vermiculite by volume and adjusted with lime to a $\mathrm{pH}$ of 6.0. Maize ears from

6 the Pioneer inbred lines HC69, PH2RT, PH84Z and PH85E were collected from the greenhouse

7 (Johnston, Iowa) at 10 to $11 \mathrm{~d}$ after pollination, when the immature embryos were $1.5-2.0 \mathrm{~mm}$ in

8 length. Ears were sterilized with $20 \%$ Clorox (final sodium hypochlorite concentration of

$9 \quad 1.65 \%$ ) for $15 \mathrm{~min}$ and rinsed three times with sterile distilled water.

Culture media used for transformations and plant regeneration

11 Briefly, maize immature embryos (1.5-2 mm) were harvested and used for Agrobacterium-

12 mediated transformation, using the media, selection and regeneration methods described

13 previously (Lowe et al., 2018; Chu et al., 2019;Hoerster et al., 2020). All media recipes are

14 described by (Lowe et al., 2018; Chu et al., 2019; Hoerster et al., 2020). For selection, $0.1 \mathrm{mg} / \mathrm{L}$

15 imazapyr was supplemented to somatic embryo formation medium or $150 \mathrm{mg} / \mathrm{L}$ G418 was

16 substituted for imazapyr.

17

18 Agrobacterium-mediated transformation

19 Constructs used in these experiments are illustrated in Figures 1, 2, and 4 and the individual

20 expression components such as promoters, structural genes and terminators are listed in Table S

21 1. The materials reported in this article contain selectable markers (HRA and NPTII) and reporter

22 genes (ZS-Green and Zs-Yellow) are owned by third parties. Authors may not be able to provide

23 materials including third party genetic elements to the requestor because of certain third-party 
1 contractual restrictions placed on the author's institution. In such cases, the requester will be

2 required to obtain such materials directly from the third party. The authors and authors'

3 institution do not make any express or implied permission(s) to the requester to make, use, sell,

4 offer for sale, or import third party proprietary materials.

5

6 medium, or the $U b i_{p r o}:: N P T I I$ gene for selection with $150 \mathrm{mg} / \mathrm{L} \mathrm{G} 418$ in culture medium.

All transformations were done using the thymidine auxotrophic Agrobacterium tumefaciens strain LBA4404 THY- containing pVIR9 (Anand et al., 2018) at OD 550 of 0.5. The conditions for Agrobacterium suspension culture preparation following embryo isolation and infection has been previously described (Lowe et al., 2018; Hoerster et al., 2020). Two selectable markers were used in experiments: $H R A$ (Green et al., 2009), a sulfonylurea herbicide resistance marker, driven by the sorghum $A l s$ promoter for selection with $0.1 \mathrm{mg} / \mathrm{L}$ imazapyr in culture

\section{Excision conditions}

15 For the developmentally regulated pro::Cre testing, no optimization was required. These 16 experiments were performed on two inbreds, HC69 and PHR2HT. The initial heat shock

17 treatment for excision involved three different conditions: no heat shock (control), heat shock at $1837^{\circ} \mathrm{C}$ for $1 \mathrm{day}$, or $42^{\circ} \mathrm{C}$ for $2 \mathrm{~h} /$ day for 3 consecutive days, were tested. We further optimized the 19 heat shock condition testing three additional heat treatments 1) $42^{\circ} \mathrm{C}, 2 \mathrm{~h} /$ day for $2 \mathrm{~d}, 2$ ) $42^{\circ} \mathrm{C}$ for $2024 \mathrm{~h}$, or 3$) 45^{\circ} \mathrm{C}$ for $2 \mathrm{~h} /$ day to identify a treatment that is best and simple for implementation.

\section{Molecular analyses}


1 All molecular analysis and transgene copy number determination methods were previously

2 described (Wu et al., 2014; Lowe et al., 2016;Hoerster et al., 2020). qPCR data was used to

3 confirm recombinase-mediated excision based on the absence the transgenes flanked by the loxP

4 sites, determine the copy number of structural genes outside the excision DNA, and to screen for

5 the presence of Agrobacterium binary construct backbone integration. Genomic DNA samples

6 were extracted from a single piece (200 ng) of fresh leaf tissue from each plant (Truett et al.,

7 2000). Non-transgenic maize inbred lines were used as the negative controls. Quantification

8 was based on detection of amplified gene sequences using gene-specific forward and reverse

9 primers, along with the corresponding gene-specific $\mathrm{FAM}^{\mathrm{TM}}$ or $\mathrm{Vic}^{\circledR}$-based MGB fluorogenic

10 probes (Applied Biosystems). The 2- $\Delta \Delta \mathrm{CT}$ method (Livak and Schmittgen, 2001) was used to

11 estimate copy number. Events which are single copy for all the transgenes and excised was used

12 to calculate the excision frequency. The events which are excised with a single copy (SC) of all

13 the transgenes without vector backbone integration were defined as a quality event (QE). The

14 usable event (UE) frequency was calculated as transformation frequency times QE frequency.

15 Data collected from different experiments were analyzed separately by analysis of variance

16 (ANOVA), with mean separation by LSD $(\mathrm{P}=0.05)$ using JMP Pro 12.2.0 Statistical Discovery

17 software package (SAS Institute Inc., Cary, NC).

\section{CONCLUSION}

20 Despite the recent progress in developing a rapid maize transformation, the presence of

21 morphogenic genes in the transgenic event have shown to result in pleiotropic phenotypes and is

22 not recommended for transgene testing or commercial product development. The first generation

23 of rapid maize transformation method was designed to improve the transformation rates and to 
1 extend transformation capabilities to many genotypes. Subsequently, we demonstrated a viable

2 second-generation alternative, using a mixture of an Agrobacterium strains, one with non-

3 integrating Wus2 gene and the other with a combination of structural genes to regenerate

4 transgenic plants free of morphogenic genes. Even though this simplifies vector construction,

5 however, the process still relies on SMG for recovery of stable transgenic events. This study

6 demonstrated a viable third alternative, relying on inducible promoters for auto-excision of both

7 the morphogenic genes and the SMG in the early stages of maize transformation. The stable

8 transformed plants recovered by this method are free of the morphogenic genes and marker

9 genes, a desirable quality for transgene evaluation and in commercial products.

\section{AUTHOR CONTRIBUTION STATEMENT}

12 A.A., E.W., L.K., W.G-K., T.J., and N.D.A conceived the research idea, A.A., E.W., L.K., and

13 W.G-K. designed constructs and research, and N.W., MA., HG. and R.L conducted maize

14 transformation and optimization; E.W. and A.A, performed data analysis; A.A., W.G-K . T.J., 15 and N.D.C. wrote the manuscript.

\section{CONFLICT OF INTEREST}

18 NW, MA, HG, RL, EW, LK, W.G-K and AA are inventors on pending applications on this work

19 and a related work are current employees of Corteva Agriscience who owns the pending patent

20 applications. TJ and NDC are current employees of Corteva Agriscience. 
1 We thank the internal support groups, Super-Vector (SV) team for their support with vector

2 construction and PCR Analysis and Characterization (PAC) team for molecular event quality

3 analysis. Scott Betts with program support, Terry Hu for maize transformation support. Special

4 thanks to Tracy Fisher and Scott Betts for critical reading of the manuscript and Kara Califf for

5 the art work. 


\section{References}

An, G. (1986). Development of plant promoter expression vectors and their use for analysis of differential activity of nopaline synthase promoter in transformed tobacco cells. Plant Physiol. 81, 86-91.

An, G., Mitra, A., Choi, H.K., Costa, M.A., An, K., Thornburg, R.W., and Ryan, C.A. (1989). Functional analysis of the 3 ' control region of the potato wound-inducible proteinase inhibitor II gene. The Plant Cell 1, 115-122.

Anand, A., Arling, M.L., Da Silva Conceicao, A., Gordon-Kamm, W.J., Hastings, C.E., Hoerster, G.M. et al, (2017a). Methods and compositions for rapid plant transformation. United States patent US20170121722A1

Anand, A., Bass, S.H., Bertain, S.M., Cho, H.J., Kinney, A.J., Klein, T.M., etal. (2017b). Ochrobactrum-mediated transformation of plants. International patent WO2017040343A1

Anand, A., Bass, S.H., Wu, E., Wang, N., Mcbride, K.E., Annaluru, N., Miller, M., Hua, M., and Jones, T.J. (2018). An improved ternary vector system for Agrobacterium-mediated rapid maize transformation. Plant Mol Biol 97, 187-200.

Araki, H., Jearnpipatkul, A., Tatsumi, H., Sakurai, T., Ushio, K., Muta, T., and Oshima, Y. (1985). Molecular and functional organization of yeast plasmid pSR1. J. Mol. Biol. 182, 191-203.

Bayley, C.C., Morgan, M., Dale, E.C., and Ow, D.W. (1992). Exchange of gene activity in transgenic plants catalyzed by the Cre-lox site-specific recombination system. Plant Mol. Biol. 18, 353-361.

Belanger, F.C., and Kriz, A.L. (1991). Molecular basis for allelic polymorphism of the maize Globulin-1 gene. Genetics 129, 863-872.

Bhyri, P., Khrishnamurthy, N., Narayanan, E., Nott, A., and Sarangi, R. (2014). Novel plant terminator sequences. United States patent US20140130205.

Bolduc, N., Yilmaz, A., Mejia-Guerra, M.K., Morohashi, K., O'connor, D., Grotewold, E., and Hake, S. (2012). Unraveling the KNOTTED1 regulatory network in maize meristems. Genes Dev.26, 1685-1690.

Busk, P.K., Jensen, A.B., and Pagès, M. (1997). Regulatory elements in vivo in the promoter of the abscisic acid responsive gene rab17 from maize. Plant J. 11, 1285-1295.

Casper, L., Lappegard, K.K., Abbitt, S.E., Martino-Catt, S.J., and Olsen, O.A. (2005). Seedpreferred promoters from end genes. United States patent US6903205B2.

Chilcoat, D., Liu, Z.-B., and Sander, J. (2017). "Chapter Two - Use of CRISPR/Cas9 for Crop Improvement in Maize and Soybean," in Progress in Molecular Biology and Translational Science, eds. D.P. Weeks \& B. Yang. Academic Press), 27-46.

Chong-Pérez, B., and Angenon, G. (2013). "Strategies for generating marker-free transgenic plants" in Genetic Engineering, ed. I. Sithole-Niang. Intech Open.

Christensen, A.H., Sharrock, R.A., and Quail, P.H. (1992). Maize polyubiquitin genes: structure, thermal perturbation of expression and transcript splicing, and promoter activity following transfer to protoplasts by electroporation. Plant Mol Biol. 18, 675-689.

Chu, U.C., Adelberg, J., Lowe, K., and Jones, T.J. (2019). Use of DoE methodology to optimize the regeneration of high-quality, single-copy transgenic Zea mays L. (maize) plants. In Vitro Cell. Dev. Biol. Plant 55, 678-694 
Cox, M.M. (1983). The FLP protein of the yeast 2-microns plasmid: expression of a eukaryotic genetic recombination system in Escherichia coli. Proc. Natl. Acad. Sci. U.S.A 80, 42234227.

Cuellar, W., Gaudin, A., Solórzano, D., Casas, A., Ñopo, L., Chudalayandi, P., Medrano, et al. (2006). Self-excision of the antibiotic resistance gene nptII using a heat inducible CreloxP system from transgenic potato. Plant Mol. Biol. 62, 71-82.

Dale, E.C., and Ow, D.W. (1991). Gene transfer with subsequent removal of the selection gene from the host genome. Proc. Natl. Acad. Sci. U.S.A 88, 10558-10562.

Darbani, B., Eimanifar, A., Stewart Jr., C.N., and Camargo, W.N. (2007). Methods to produce marker-free transgenic plants. Biotechnol. J. 2, 83-90.

Du, D., Jin, R., Guo, J., and Zhang, F. (2019). Construction of marker-free genetically modified maize using a heat-inducible auto-excision vector. Genes 10, 374.

Gao, X., Zhou, J., Li, J., Zou, X., Zhao, J., Li, Q., et. al. (2015). Efficient generation of markerfree transgenic rice plants using an improved transposon-mediated transgene reintegration strategy. Plant Physiol.167, 11-24.

Garnaat, C., Lowe, K., S., and Roth, B., A (2002). Zm-AXIG1-specific polynucleotides and methods of use. United States patent application US2001022169

Gatz, C. (1996). Chemically inducible promoters in transgenic plants. Curr. Opin Biotechnol. 7, $168-172 .$.

Gleave, A.P., Mitra, D.S., Mudge, S.R., and Morris, B.a.M. (1999). Selectable marker-free transgenic plants without sexual crossing: transient expression of cre recombinase and use of a conditional lethal dominant gene. Plant Mol. Biol. 40, 223-235.

Gordon-Kamm, W.J., Helentjaris, T., Lowe, K., Shen, B., Tarczynski, M., and Zheng, P. (2005). Ap2 domain transcription factor Odp2 (ovule development protein 2) and methods of use. International patent WO2005075655A2

Green, J.M., Hale, T., Pagano, M.A., Andreassi, J.L., and Gutteridge, S.A. (2009). Response of 98140 corn with Gat4621 and HRA transgenes to glyphosate and ALS-inhibiting herbicides. Weed Sci. 57, 142-148.

Hare, P.D., and Chua, N.H. (2002). Excision of selectable marker genes from transgenic plants. Nat. Biotechnol. 20, 575-580.

Hershey, H.P., and Stoner, T.D. (1991). Isolation and characterization of cDNA clones for RNA species induced by substituted benzenesulfonamides in corn. Plant Mol. Biol. 17, 679690.

Hoerster, G., Wang, N., Ryan, L., Wu, E., Anand, A., McBride, K., et al. (2020). Use of nonintegrating Zm-Wus2 vectors to enhance maize transformation. In Vitro Cell. Dev. Biol. Plant. 10.1007/s11627-019-10042-2

Hoess, R.H., and Abremski, K. (1985). Mechanism of strand cleavage and exchange in the Crelox site-specific recombination system. J. Mol. Biol. 181, 351-362.

Hoess, R.H., Ziese, M., and Sternberg, N. (1982). P1 site-specific recombination: nucleotide sequence of the recombining sites. Proc. Natl. Acad. Sci. U.S.A 79, 3398-3402.

Hu, X., Liu, R., Li, Y., Wang, W., Tai, F., Xue, R., and Li, C. (2010). Heat shock protein 70 regulates the abscisic acid-induced antioxidant response of maize to combined drought and heat stress. Plant Growth Regul. 60, 225-235.

Jia, H., Pang, Y., Chen, X., and Fang, R. (2006). Removal of the selectable marker gene from transgenic tobacco plants by expression of cre recombinase from a tobacco mosaic virus vector through agroinfection. Transgenic. Res. 15, 375-384. 
Kalla, R., Shimamoto, K., Potter, R., Nielsen, P.S., Linnestad, C., and Olsen, O.-A. (1994). The promoter of the barley aleurone-specific gene encoding a putative $7 \mathrm{kDa}$ lipid transfer protein confers aleurone cell-specific expression in transgenic rice. Plant J. 6, 849-860.

Kerbach, S., Lörz, H., and Becker, D. (2005). Site-specific recombination in Zea mays. Theor. Appl. Genet. 111, 1608-1616.

Kilby, N.J., Davies, G.J., Snaith, M.R., and Murray, J.A.H. (1995). FLP recombinase in transgenic plants: constitutive activity in stably transformed tobacco and generation of marked cell clones in Arabidopsis. Plant J. 8, 637-652.

Klippel, A., Mertens, G., Patschinsky, T., and Kahmann, R. (1988). The DNA invertase Gin of phage $\mathrm{Mu}$ : formation of a covalent complex with DNA via a phosphoserine at amino acid position 9. EMBO J. 7, 1229-1237.

Kopertekh, L., Jüttner, G., and Schiemann, J. (2004). PVX-Cre-mediated marker gene elimination from transgenic plants. Plant Mol.Biol. 55, 491-500.

Kopertekh, L., and Schiemann, J. (2005). Agroinfiltration as a tool for transient expression of cre recombinase in vivo. Transgenic Res.14, 793-798.

Kriz, A.R., Wallace, M.S., and Paiva, R. (1990). Globulin gene expression in embryos of maize viviparous mutants. Plant Physiol. 92, 538-542.

Ling, F., Zhou, F., Chen, H., and Lin, Y. (2016). Development of marker-free insect-resistant indica rice by Agrobacterium tumefaciens-mediated co-transformation. Front. Plant Sci. 7 (448).

Liu, S., Kriz, A., Duncan, D., and Widholm, J. (1998). Abscisic acid-regulated Glb1 transient expression in cultured maize P3377 cells. Plant Cell Rep. 17, 650-655.

Livak, K.J., and Schmittgen, T.D. (2001). Analysis of relative gene expression data using realtime quantitative pcr and the 2- $\Delta \Delta \mathrm{CT}$ method. Methods 25, 402-408.

Lowe, K., La Rota, M., Hoerster, G., Hastings, C., Wang, N., Chamberlin, M., et al. (2018). Rapid genotype "independent" Zea mays L. (maize) transformation via direct somatic embryogenesis. In Vitro Cell. Dev. Biol. Plant 54, 240-252.

Lowe, K., Wu, E., Wang, N., Hoerster, G., Hastings, C., Cho, M.-J., et al (2016). Morphogenic regulators baby boom and wuschel improve monocot transformation. Plant Cell 28, 1998-2015.

Lowe, K.S., Cahoon, R.E., Scelonge, C.J., Tao, Y., Gordon-Kamm, W.J., Bruce, W.B., and Newman, L.J. (2007). Wuschel (WUS) gene homologs. United States patent US 20077256322B2

Maeser, S., and Kahmann, R. (1991). The Gin recombinase of phage Mu can catalyse sitespecific recombination in plant protoplasts. Mol. Gen. Genet. 230, 170-176.

Maher, M.F., Nasti, R.A., Vollbrecht, M., Starker, C.G., Clark, M.D., and Voytas, D.F. (2020). Plant gene editing through de novo induction of meristems. Nat. Biotechnol. 38, 84-89.

Matz, M.V., Fradkov, A.F., Labas, Y.A., Savitsky, A.P., Zaraisky, A.G., Markelov, M.L., and Lukyanov, S.A. (1999). Fluorescent proteins from nonbioluminescent Anthozoa species. Nat. Biotechnol. 17, 969-973.

Mookkan, M., Nelson-Vasilchik, K., Hague, J., Zhang, Z.J., and Kausch, A.P. (2017). Selectable marker independent transformation of recalcitrant maize inbred B73 and sorghum P898012 mediated by morphogenic regulators BABY BOOM and WUSCHEL2. Plant Cell Rep. 36, 1477-1491. 
Moravčíková, J., Vaculková, E., Bauer, M., and Libantová, J. (2008). Feasibility of the seed specific cruciferin $\mathrm{C}$ promoter in the self excision Cre/loxP strategy focused on generation of marker-free transgenic plants. Theor. Appl. Genet. 117, 1325.

Odell, J., Caimi, P., Sauer, B., and Russell, S. (1990). Site-directed recombination in the genome of transgenic tobacco. Mol. Gen. Genet. 223, 369-378.

Pegoraro, C., Mertz, L.M., Da Maia, L.C., Rombaldi, C.V., and De Oliveira, A.C. (2011). Importance of heat shock proteins in maize. J.Crop Sci Biotechnol. 14, 85-95.

Pelletier, J.M., Kwong, R.W., Park, S., Le, B.H., Baden, R., Cagliari, A., et al. (2017). LEC1 sequentially regulates the transcription of genes involved in diverse developmental processes during seed development. Proc. Natl. Acad. Sci. U.S.A 114, E6710-E6719.

Puchta, H. (2000). Removing selectable marker genes: taking the shortcut. Trends Plant Sci.5, 273-274.

Puchta, H. (2003). Marker-free transgenic plants. Plant Cell Tissue Organ Cult. 74, 123-134.

Ristic, Z., Gifford, D.J., and Cass, D.D. (1991). Heat shock proteins in two lines of Zea mays L. that differ in drought and heat resistance. Plant Physiol. 97, 1430-1434.

Senecoff, J.F., Bruckner, R.C., and Cox, M.M. (1985). The FLP recombinase of the yeast 2micron plasmid: characterization of its recombination site. Proc. Natl. Acad. Sci. U.S.A $82,7270-7274$.

Shane, E.A. (2007). Early endosperm promoter EEP1. United States patent US 780399 B2.

Truett, G.E., Heeger, P., Mynatt, R.L., Truett, A.A., Walker, J.A., and Warman, M.L. (2000). Preparation of PCR-quality mouse genomic dna with hot sodium hydroxide and tris (HotSHOT). BioTechniques 29, 52-54.

Verweire, D., Verleyen, K., De Buck, S., Claeys, M., and Angenon, G. (2007). Marker-free transgenic plants through genetically programmed auto-excision. Plant Physiol. 145, 1220-1231.

Vierling, E. (1991). The roles of heat shock proteins in plants. Annu. Rev. Plant Physiol.Plant Mol. Biol. 42, 579-620.

Vilardell, J., Mundy, J., Stilling, B., Leroux, B., Pla, M., Freyssinet, G., and Pagès, M. (1991). Regulation of the maize rab17 gene promoter in transgenic heterologous systems. Plant Mol Biol 17, 985-993.

Wu, E., Lenderts, B., Glassman, K., Berezowska-Kaniewska, M., Christensen, H., Asmus, T., et al. (2014). Optimized Agrobacterium-mediated sorghum transformation protocol and molecular data of transgenic sorghum plants. In Vitro Cell. Dev. Biol. Plant 50, 9-18.

Yau, Y.Y., and Stewart, C.N., Jr. (2013). Less is more: strategies to remove marker genes from transgenic plants. BMC Biotechnol. 13, 36-36.

Zhang, Y., Li, H., Ouyang, B., Lu, Y., and Ye, Z. (2006). Chemical-induced autoexcision of selectable markers in elite tomato plants transformed with a gene conferring resistance to lepidopteran insects. Biotechnol. Lett. 28, 1247-1253.

Zubko, E., Scutt, C., and Meyer, P. (2000). Intrachromosomal recombination between attP regions as a tool to remove selectable marker genes from tobacco transgenes. Nat. Biotechnol. 18, 442-445.

Zuo, J., and Chua, N.-H. (2000). Chemical-inducible systems for regulated expression of plant genes. Curr. Opin.Biotech. 11, 146-151. 
1 Table 1. List of the promoters, their source, and their expression pattern in plants.

\begin{tabular}{|c|c|c|c|}
\hline Promoters & Source & Expression & Reference \\
\hline$K n 1$ & Maize & Apical Meristem & Gen bank AY312169 \\
\hline Lecl & Maize & Early Embryo & (Shane, 2007) \\
\hline End2 & Maize & Early Embryo & (Casper et al., 2005) \\
\hline Ltp2 & Maize & Early Embryo & (Kalla et al., 1994) \\
\hline Glb1 & Maize & Late Embryo & (Liu et al., 1998) \\
\hline Ole & Maize & Late Embryo & (Anand et al., 2017b) \\
\hline $\operatorname{Rab} 17$ & Maize & Late Embryo/Stress & (Busk et al., 1997) \\
\hline Nos & $\begin{array}{l}\text { Agrobacterium } \\
\text { tumefaciens }\end{array}$ & Constitutive & $(A n, 1986)$ \\
\hline$U b i_{p r o}$ & Maize & Constitutive & (Christensen et al., 1992) \\
\hline Hsp17.7 & Maize & Heat shock inducible & (Anand et al., 2017a) \\
\hline Hsp26 & Maize & Heat shock inducible & (Anand et al., 2017a) \\
\hline Rab21 & Seteria itallica & Drought inducible & $\begin{array}{l}\text { Previously unpublished Corteva } \\
\text { Agriscience sequence Si026926m }\end{array}$ \\
\hline Drp12 & $\begin{array}{l}\text { Brachypodium } \\
\text { distachyon }\end{array}$ & Drought inducible & $\begin{array}{l}\text { Previously unpublished Corteva } \\
\text { Agriscience sequence Bradi3g43870.1 }\end{array}$ \\
\hline Drpl & $\begin{array}{l}\text { Brachypodium } \\
\text { distachyon }\end{array}$ & Drought inducible & $\begin{array}{l}\text { Previously unpublished Corteva } \\
\text { Agriscience sequence Bradilg37410.1 }\end{array}$ \\
\hline
\end{tabular}


1 Table 2. Transformation results with different developmentally regulated promoters driving Cre expression for auto-excision of

2 morphogenic genes using construct design described in Figure 1. Data presents the T0 transformation frequency, qPCR detection of

3 the number of excised events and the quality event frequency in two different inbreds, PH2RT and HC69.

\begin{tabular}{|c|c|c|c|c|c|c|c|c|}
\hline Inbred & Promoter & $\begin{array}{l}\text { Embryos } \\
\text { transformed }\end{array}$ & T0 plants & $\begin{array}{l}\mathrm{T} 0 \\
\text { transformation } \\
\text { frequency } \\
(\% \pm \mathrm{SE})\end{array}$ & $\begin{array}{l}\text { Excised } \\
\text { single copy, } \\
\text { backbone- } \\
\text { free events }\end{array}$ & $\begin{array}{l}\text { Excision } \\
\text { frequency } \\
(\%)\end{array}$ & $\begin{array}{l}\text { Quality } \\
\text { event } \\
(\%)\end{array}$ & $\begin{array}{l}\text { Usable } \\
\text { events } \\
(\%)\end{array}$ \\
\hline \multirow[t]{5}{*}{ PH2RT } & Ltp2 & 229 & 75 & $32.8(2.2)^{\mathrm{a}}$ & 10 & 50 & 13.3 & 4.4 \\
\hline & Ole & 228 & 59 & $27.2(3.3)^{a b}$ & 8 & 40 & 13.6 & 3.5 \\
\hline & Glb1 & 280 & 38 & $13.6(1.4)^{\mathrm{c}}$ & 7 & 58.5 & 18.4 & 2.5 \\
\hline & End2 & 174 & 39 & $22.4(2.6)^{b}$ & 3 & 100 & 7.7 & 1.7 \\
\hline & $U b i$ & 440 & 40 & $9.1(1.9)^{\mathrm{c}}$ & 12 & 59.1 & 30.0 & 2.7 \\
\hline \multirow[t]{5}{*}{ HC69 } & Rab17 & 121 & 35 & $28.9(2.6)^{b}$ & 1 & 25 & 2.9 & 0.8 \\
\hline & Ole & 151 & 49 & $37.1(2.1)^{\mathrm{a}}$ & 3 & 37.5 & 6.1 & 2.0 \\
\hline & Glb1 & 230 & 58 & $25.2(1.8)^{b}$ & 5 & 38.5 & 8.6 & 2.2 \\
\hline & End2 & 178 & 48 & $27.0(2.4)^{b}$ & 1 & 100 & 2.1 & 0.6 \\
\hline & $U b i$ & 202 & 37 & $18.3(1.2)^{\mathrm{c}}$ & 3 & 13.6 & 8.1 & 1.5 \\
\hline
\end{tabular}

\footnotetext{
5

6 Data from three independent transformers was used to determine T0 transformation frequency. The quality events (QE) were identified as single copy, backbone-

7 free, and morphogenic gene-free (excised). The excision frequency was determined as the ratio of the number of excised single-copy events relative to the total

8 single-copy events. The number QEs was divided by the total number of events recovered to calculate the QE frequency. The usable event (UE) frequency is a

9 measure of the number of acceptable transgenic events per 100 embryos that was determined as the product of QE frequency and T0 transformation frequency.

10 Mean values followed by the same letter are not statistically different from each other at the significance level of 0.05.
} 
Table 3. Transformation results from excision-activated marker gene selection using either the Glb1 $1_{\text {pro }}$ or the Ole pro driving Cre

2 expression using construct design described in Figure 2. Data presents the T0 transformation frequency, qPCR detection of the number

3 of excised events and the quality event frequency in maize inbred HC69.

\begin{tabular}{ccclclccc}
\hline Promoter & $\begin{array}{l}\text { Embryos } \\
\text { transformed }\end{array}$ & T0 plants & $\begin{array}{l}\text { T0 } \\
\text { transformation } \\
\text { frequency } \\
(\% \pm \text { SE) }\end{array}$ & $\begin{array}{l}\text { Total } \\
\text { single } \\
\text { copy } \\
\text { events }\end{array}$ & $\begin{array}{l}\text { Excised single } \\
\text { copy, } \\
\text { backbone-free } \\
\text { events }\end{array}$ & $\begin{array}{l}\text { Excision } \\
\text { frequency } \\
(\%)\end{array}$ & $\begin{array}{l}\text { Quality } \\
\text { event }(\%)\end{array}$ & $\begin{array}{l}\text { Usable } \\
\text { events }(\%)\end{array}$ \\
\hline Glb1 & 126 & 57 & $44.7(2.8)^{\text {a }}$ & 19 & 13 & 68.4 & 13.3 & 5.6 \\
Ole & 112 & 45 & $40.2(1.9)^{\mathrm{a}}$ & 15 & 8 & 53.3 & 8.8 \\
\hline
\end{tabular}

4

5 Data from two independent transformers was used to determine T0 transformation frequency. Quality events (QE) were identified as single copy, backbone-free,

6 and morphogenic gene-free (excised). The excision frequency was determined as the ratio of the number of excised single-copy events relative to the total single-

7 copy events. The number QEs was divided by the total number of events recovered to calculate the QE frequency. The usable event (UE) frequency is a

8 measure of the number of acceptable transgenic events per 100 embryos that was determined as the product of QE frequency and transformation frequency.

9 Mean values followed by the same letter are not statistically different from each other at the significance level of 0.05 . 
Table 4. Transformation results from excision-activated marker gene selection using $G l b_{\text {pro }}$ driving Cre expression using construct

2 design described in Figure 2. Data presents the T0 transformation frequency, qPCR detection of the number of excised events and the

3 quality event frequency in three maize inbreds (HC69, PH85E, and PH84Z).

\begin{tabular}{llllllll}
\hline Inbred & $\begin{array}{l}\text { Embryos } \\
\text { transformed }\end{array}$ & $\begin{array}{l}\text { T0 } \\
\text { plants }\end{array}$ & $\begin{array}{l}\text { T0 } \\
\text { transformation } \\
(\% \pm \mathrm{SE})\end{array}$ & $\begin{array}{l}\text { Excised single } \\
\text { copy, backbone- } \\
\text { free events }\end{array}$ & $\begin{array}{l}\text { Excision } \\
\text { frequency } \\
(\%)\end{array}$ & $\begin{array}{l}\text { Quality } \\
\text { event }(\%)\end{array}$ & $\begin{array}{l}\text { Usable } \\
\text { events }(\%)\end{array}$ \\
\hline HC69 & 393 & 196 & $49.9(3.9)^{\mathrm{a}}$ & 17 & 55.0 & 8.7 & 4.3 \\
PH85E & 363 & 47 & $12.9(1.3)^{\mathrm{c}}$ & 13 & 59.0 & 27.7 & 3.6 \\
PH84Z & 367 & 105 & $28.6(2.5)^{\mathrm{b}}$ & 7 & 61.0 & 6.7 & 1.9 \\
\hline
\end{tabular}

4

5 Data from two independent transformers was used to determine T0 transformation frequency. The quality events (QE) were identified as single copy, backbone-

6 free, and morphogenic gene-free (excised). The excision frequency was determined as the ratio of the number of excised single-copy events relative to the total

7 single-copy events. The number QEs was divided by the total number of events recovered to calculate the QE frequency. The usable event (UE) frequency is a

8 measure of the number of acceptable transgenic events per 100 embryos that was determined as the product of QE frequency and transformation frequency.

9 Mean values followed by the same letter are not statistically different from each other at the significance level of 0.05 . 
1 Table 5. Transformation results from screening of six different inducible promoters driving Cre expression for controlled gene

2 excision. For this study, three different conditions were evaluated: two heat shock treatments $\left(37^{\circ} \mathrm{C}\right.$ for 1 day and $42^{\circ} \mathrm{C}, 2 \mathrm{~h} / \mathrm{day}$ for 3

3 consecutive days) and no heat (control). Data presents the qPCR detection of the number of excised events and excision frequency

4 across the different promoters, and a control construct without the Cre gene, in maize inbred HC69.

5

\begin{tabular}{|c|c|c|c|c|c|c|c|c|c|c|c|c|}
\hline \multirow{3}{*}{ Promoter } & \multicolumn{5}{|c|}{ Control } & \multicolumn{3}{|c|}{$37^{\circ} \mathrm{C}, 1$ day } & \multicolumn{4}{|c|}{$42^{\circ} \mathrm{C}, 2 \mathrm{~h} /$ day for 3 days } \\
\hline & & T0 & & $\begin{array}{l}\text { Excision } \\
\text { frequency }\end{array}$ & & T0 & & $\begin{array}{l}\text { Excision } \\
\text { frequency }\end{array}$ & & T0 & & $\begin{array}{l}\text { Excision } \\
\text { frequency }\end{array}$ \\
\hline & Embryos & plants & $\mathrm{QE}$ & $(\%)$ & Embryos & plants & $\mathrm{QE}$ & $(\%)$ & Embryos & plants & $\mathrm{QE}$ & $(\%)$ \\
\hline Hsp17.7 & 455 & 59 & 5 & 27.8 & 50 & 6 & 2 & 66.7 & 50 & 20 & 4 & 100 \\
\hline Hsp26 & 450 & 98 & 0 & 0.0 & 50 & 5 & 0 & 0 & 50 & 21 & 3 & 43 \\
\hline Rab17 & 455 & 127 & 1 & 3.4 & 50 & 10 & 0 & 0 & 50 & 18 & 0 & 0 \\
\hline Rab21 & 455 & 101 & 8 & 36.4 & 50 & 13 & 1 & 100 & 50 & 20 & 0 & 0 \\
\hline Drp12 & 450 & 79 & 2 & 11.1 & 50 & 16 & 0 & 0 & 50 & 22 & 2 & 66.7 \\
\hline Drpl & 438 & 90 & 8 & 27.6 & 50 & 8 & 0 & 0 & 50 & 27 & 5 & 45.5 \\
\hline $\begin{array}{l}\text { Control (no } \\
\text { Cre) }\end{array}$ & 450 & 182 & 0 & & & & & & & & & \\
\hline
\end{tabular}

7 Data from two independent transformers was used to determine T0 transformation frequency. The quality events (QE) were identified as single copy, backbone-

8 free, and morphogenic gene-free (excised). The excision frequency was determined as the ratio of the number of excised single-copy events relative to the total

9 single-copy events. 
1 Table 6. Transformation results optimizing the heat shock conditions for controlled gene excision using three inducible promoters

2 driving $\mathrm{Cre}$ expression. The three different conditions evaluated were: no heat (control) and two heat shock treatments $\left(42^{\circ} \mathrm{C}\right.$ for $2 \mathrm{~h}$

3 and $42^{\circ} \mathrm{C}, 2 \mathrm{~h}$ /day for 3 consecutive days). The data presents the qPCR detection of the number of excised events and excision

4 frequency across the different promoters in the study as compared to a control construct without the Cre gene in maize inbred HC69.

\begin{tabular}{|c|c|c|c|c|c|c|c|c|c|c|c|c|c|c|c|}
\hline \multirow[b]{2}{*}{ Promoter } & \multicolumn{5}{|c|}{ Control } & \multicolumn{5}{|c|}{$42^{\circ} \mathrm{C}, 2 \mathrm{~h}$} & \multicolumn{5}{|c|}{$42^{\circ} \mathrm{C}, 2 \mathrm{~h} /$ day for 3 days } \\
\hline & Embryos & $\begin{array}{l}\text { T0 } \\
\text { Plants }\end{array}$ & QE & $\begin{array}{l}\text { Excision } \\
\text { frequency } \\
(\%)\end{array}$ & $\begin{array}{l}\text { UE } \\
\%\end{array}$ & Embryos & $\begin{array}{l}\text { T0 } \\
\text { plants }\end{array}$ & $\mathrm{QE}$ & $\begin{array}{l}\text { Excision } \\
\text { frequency } \\
(\%)\end{array}$ & $\begin{array}{l}\text { UE } \\
(\%)\end{array}$ & Embryos & $\begin{array}{l}\text { T0 } \\
\text { plants }\end{array}$ & $\mathrm{QE}$ & $\begin{array}{l}\text { Excision } \\
\text { frequency } \\
(\%)\end{array}$ & $\begin{array}{l}\text { UE } \\
(\%)\end{array}$ \\
\hline Hsp17.7 & 50 & 18 & 1 & 12.5 & 2 & 50 & 17 & 5 & 62.5 & 10 & 50 & 15 & 9 & 69.2 & 18.0 \\
\hline Hsp26 & 50 & 18 & 0 & 0 & 0 & 50 & 21 & 2 & 42.2 & 4.0 & 50 & 9 & 2 & 66.7 & 4.0 \\
\hline Drp12 & 50 & 11 & 1 & 25 & 2 & 50 & 9 & 1 & 50.0 & 2.0 & 50 & 14 & 1 & 20.0 & 2.0 \\
\hline
\end{tabular}

6 Data from two independent transformers was used to determine T0 transformation frequency. The quality events (QE) were identified as single copy, backbone-

7 free, and morphogenic gene-free (excised). The excision frequency was determined as the ratio of the number of excised single-copy events relative to the total

8 single-copy events. The number QEs was divided by the total number of events recovered to calculate the QE frequency. The usable event (UE) frequency is a

9 measure of the number of acceptable transgenic events per 100 embryos that was determined as the product of QE frequency and transformation frequency.

10 Mean values followed by the same letter are not statistically different from each other at the significance level of 0.05 
2 expression as shown in Figure 5. Four different conditions were evaluated side-by-side using split ears including no heat (control) and

3 three heat shock treatments $\left(42^{\circ} \mathrm{C}, 2 \mathrm{~h} / \mathrm{d}\right.$ for $2 \mathrm{~d} ; 42^{\circ} \mathrm{C} / 24 \mathrm{~h}$; and $\left.45^{\circ} \mathrm{C} / 2 \mathrm{~h}\right)$. Transformation results and qPCR detection of the number of

4 excised quality events, frequencies of excision and usable event are presented.

\begin{tabular}{|c|c|c|c|c|c|c|c|}
\hline Promoter & Treatments & $\begin{array}{l}\text { Embryos } \\
\text { transformed }\end{array}$ & $\begin{array}{l}\text { T0 } \\
\text { plants }\end{array}$ & $\begin{array}{l}\text { T0 transformation } \\
(\% \pm \mathrm{SE})\end{array}$ & $\begin{array}{l}\text { Quality } \\
\text { events }\end{array}$ & $\begin{array}{l}\text { Excision } \\
\text { frequency (\%) }\end{array}$ & $\begin{array}{l}\text { Usable event } \\
(\%)\end{array}$ \\
\hline \multirow{4}{*}{ Hsp17.7 } & none & 102 & 56 & $54.9(4.4)^{\mathrm{a}}$ & 6 & 33.3 & 5.9 \\
\hline & $42^{\circ} \mathrm{C}, 2 \mathrm{~h} / \mathrm{d}, 2 \mathrm{~d}$ & 102 & 39 & $38.2(2.1)^{b}$ & 9 & 56.3 & 8.8 \\
\hline & $42^{\circ} \mathrm{C} / 24 \mathrm{~h}$ & 102 & 16 & $15.7(1.8)^{\mathrm{c}}$ & 6 & 75.0 & 5.9 \\
\hline & $45^{\circ} \mathrm{C} / 2 \mathrm{~h}$ & 102 & 50 & $49.0(3.2)^{\mathrm{a}}$ & 14 & 76.6 & 13.7 \\
\hline \multirow{4}{*}{ Hsp26 } & none & 100 & 53 & $53.0(4.0)^{\mathrm{a}}$ & 1 & 5.6 & 1.0 \\
\hline & $42^{\circ} \mathrm{C}, 2 \mathrm{~h} / \mathrm{d}, 2 \mathrm{~d}$ & 100 & 35 & $35.0(1.2)^{b}$ & 12 & 66.7 & 12.0 \\
\hline & $42^{\circ} \mathrm{C} / 24 \mathrm{~h}$ & 100 & 41 & $41.0(2.2)^{b}$ & 10 & 66.7 & 10.0 \\
\hline & $45^{\circ} \mathrm{C} / 2 \mathrm{~h}$ & 100 & 50 & $50.0(2.3)^{\mathrm{a}}$ & 13 & 61.9 & 13.0 \\
\hline
\end{tabular}

Data from two independent transformers was used to determine T0 transformation frequency. The quality events (QE) were identified as single copy, backbone-

6 free, and morphogenic gene-free (excised). The excision frequency was determined as the ratio of the number of excised single-copy events relative to the total

7 single-copy events. The number QEs was divided by the total number of events recovered to calculate the QE frequency. The usable event (UE) frequency is a

8 measure of the number of acceptable transgenic events per 100 embryos that was determined as the product of QE frequency and transformation frequency.

9 Mean values followed by the same letter are not statistically different from each other at the significance level of 0.05 . 
Table 8. Transformation results and molecular event data using the Hsp17.7 heat shock promoter for controlled excision of both

2 morphogenic gene and marker gene in three maize inbreds (HC69, PH85E, and PH84Z). Two different SMGs were evaluated, HRA

3 (resistance to the sulfonylurea herbicide ethametsulfuron) and NPTII (resistance to antibiotic G418), using the same construct design

4 with the same set of morphogenic genes as shown in Figure 5. Transformation results and qPCR detection of the number of excised

5 quality events, frequencies of excision and usable event are presented.

\begin{tabular}{|c|c|c|c|c|c|c|c|c|c|}
\hline Inbred & $\begin{array}{l}\text { Selectable } \\
\text { marker }\end{array}$ & $\begin{array}{l}\text { Embryos } \\
\text { transformed } \\
\text { (number) }\end{array}$ & $\begin{array}{l}\text { T0 } \\
\text { plants } \\
\text { (number) }\end{array}$ & $\begin{array}{l}\text { T0 } \\
\text { transformation } \\
(\%)\end{array}$ & $\begin{array}{l}\text { Excised } \\
\text { single copy, } \\
\text { backbone- } \\
\text { free events } \\
\text { (number) }\end{array}$ & $\begin{array}{l}\text { Excised single } \\
\text { copy, } \\
\text { backbone-free } \\
\text { events }(\%)\end{array}$ & $\begin{array}{l}\text { Excision } \\
\text { frequency } \\
(\%)\end{array}$ & $\begin{array}{l}\text { Usable } \\
\text { event } \\
(\%)\end{array}$ & Null (\%) \\
\hline \multirow{2}{*}{ HC69 } & NPTII & 315 & 200 & 63.5 & 46 & 23.0 & 87.1 & 14.6 & 17.1 \\
\hline & $H R A$ & 407 & 281 & 69.0 & 45 & 16.0 & 82.3 & 11.1 & 37.3 \\
\hline \multirow{2}{*}{ PH85E } & NPTII & 219 & 64 & 29.2 & 23 & 35.9 & 96.7 & 10.5 & 15.3 \\
\hline & $H R A$ & 320 & 124 & 38.8 & 31 & 25.0 & 97.2 & 9.7 & 42.5 \\
\hline \multirow{2}{*}{ PH84Z } & NPTII & 356 & 145 & 40.7 & 19 & 13.1 & 50.4 & 5.3 & 14.2 \\
\hline & $H R A$ & 365 & 169 & 46.3 & 14 & 8.3 & 59.9 & 3.8 & 41.8 \\
\hline
\end{tabular}

7 Data from two independent transformers was used to determine T0 transformation frequency. The quality events (QE) were identified as single copy, backbone-

8 free, morphogenic and marker gene-free (excised). The number of QEs was divided by the total number of events analyzed to calculate the QE frequency. The

9 excision frequency was determined as the ratio of the number of excised single-copy events relative to the total single-copy events. The usable event (UE)

10 frequency is a measure of the number of acceptable transgenic events per 100 embryos that was determined as the product of QE frequency and transformation

11 frequency. 
Table 9. Observed and expected number of homozygous, hemizygous and null plants for T-DNA integration copy number in in T1

2 generation of 13 SC excised quality events across two maize inbreds (PH84Z and HC69).

\begin{tabular}{llllllll}
\hline \multirow{2}{*}{ Inbred } & Event ID & $\begin{array}{l}\text { Total } \\
\text { Plants }\end{array}$ & Homozygous & Hemizygous & Null & $\begin{array}{l}\text { Chi- } \\
\text { square }\end{array}$ & P-value* \\
& & & & & & & \\
& & & & & & \\
& ZMYF66.001.83A & 23 & 7 & 11 & 5 & 0.39 & 0.82 \\
& ZMCJK9.001.74A & 31 & 10 & 13 & 8 & 0.76 & 0.68 \\
& ZMCJK9.001.13A & 30 & 8 & 18 & 4 & 2.03 & 0.36 \\
PH84Z & ZMCJK9.001.96A & 32 & 6 & 17 & 9 & 0.69 & 0.71 \\
& ZMCJK9.001.34A & 30 & 10 & 12 & 8 & 1.5 & 0.47 \\
& ZMCJK9.001.77A & 24 & 5 & 10 & 9 & 2 & 0.36 \\
& ZMCJK9.001.3A & 27 & 4 & 17 & 6 & 2.07 & 0.35 \\
\hline HC69 & & & & & & \\
& ZMNW4W.001.72A & 23 & 11 & 7 & 5 & 6.65 & 0.03 \\
& ZMNW4W.001.30A & 31 & 11 & 13 & 7 & 1.83 & 0.39 \\
& ZMNW32.001.49A & 32 & 4 & 17 & 11 & 3.19 & 0.2 \\
& ZMNW32.001.43A & 32 & 9 & 14 & 9 & 0.35 & 0.84 \\
& ZMNW32.001.65A & 32 & 9 & 10 & 13 & 5.5 & 0.06 \\
\hline
\end{tabular}

3

* No statistically significant deviations identified from expected 1:2:1 (homozygous:hemizygous:null) segregation at 5\% level 
1 Figure 1. Schematic representation of an auto-excision construct design used for testing different

2 developmentally regulated or stress-inducible promoters to achieve excision of morphogenic

3 genes. A) The excision construct with different promoter combinations driving Cre expression

4 (represented by pro:CRE) and the DNA fragment to be excised flanked by two directly oriented

5 loxP recombination sites. B) The excised product following auto-excision. Refer to Table S-1 for

6 description of construct components used in T-DNA construction.

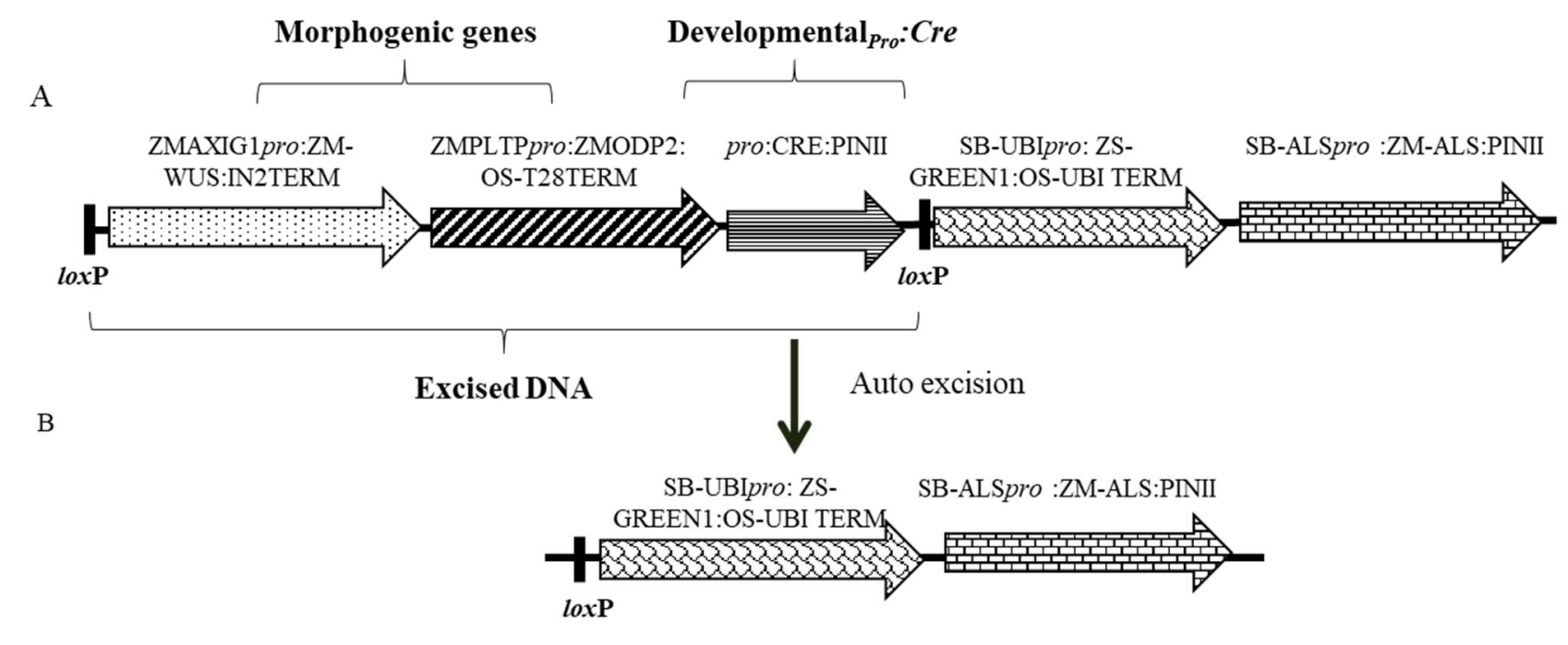


1 Figure 2. Schematic representation of an auto-excision construct design used for testing

2 developmentally regulated promoters driving Cre expression (represented by pro:CRE) for

3 excision-activated SMG expression. A) An excision-activated selectable marker construct design

4 with the DNA fragment to be excised flanked by two directly oriented loxP recombination sites.

5 B) Following excision, the $H R A$ gene is activated and events are selected on a media

6 supplemented with $0.1 \mathrm{mg} / \mathrm{L}$ imazapyr. Refer to Table S-1 for description of construct

7 components used in T-DNA construction.

A
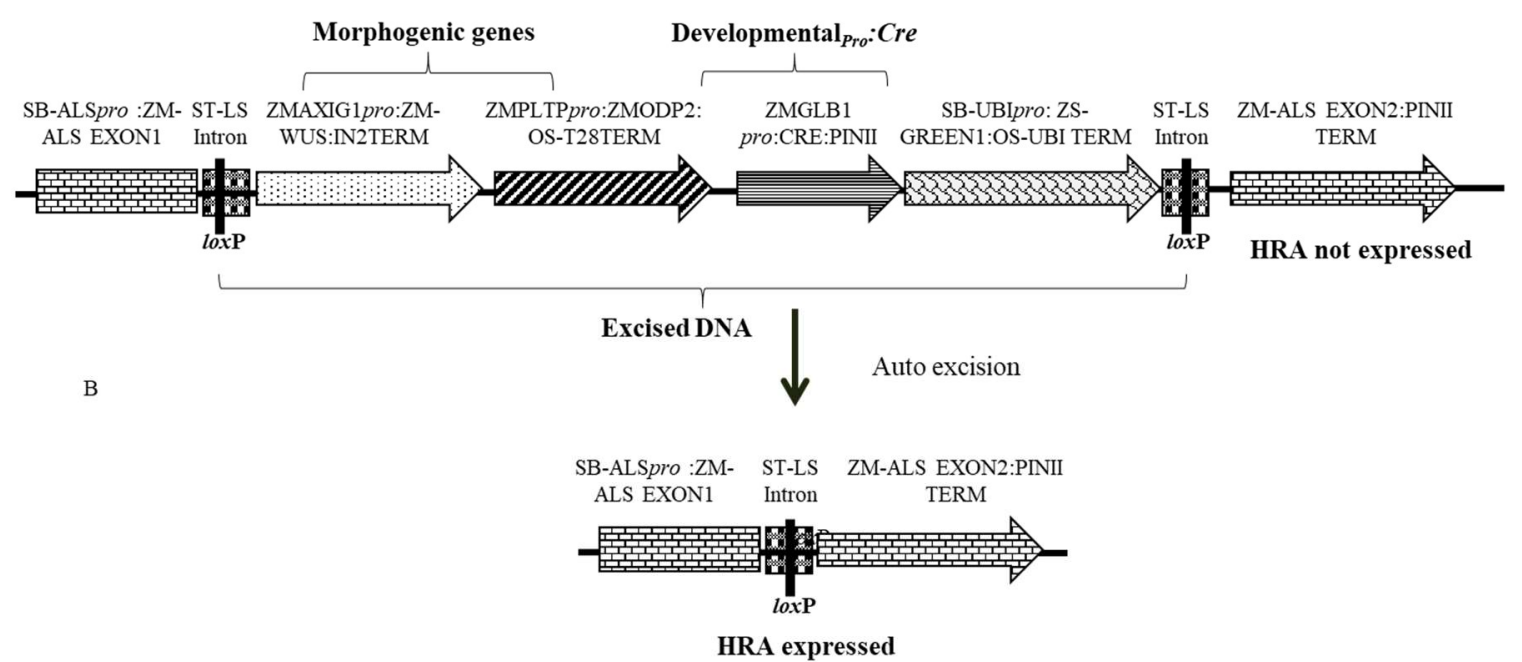
1 Figure 3. The different stages in rapid maize transformation and heat shock treatment. A)

2 immature zygotic embryos are isolated and infected with Agrobacterium tumefaciens, (B)

3 transgenic somatic embryos are placed for 3 weeks on selection media based on selectable

4 marker used (HRA or NPTII), (C) somatic embryos are heat shock treated and transferred to

5 maturation media, (D) transgenic plants are regenerated without selection pressure for 2 weeks

6 and, (E) regenerated plants are placed on a rooting media for 2-3 weeks.

A

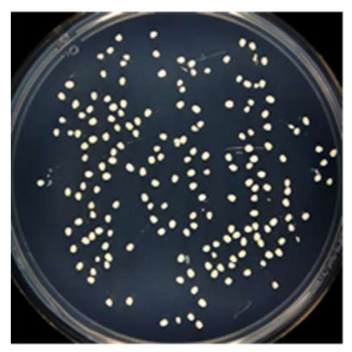

$\mathrm{B}$

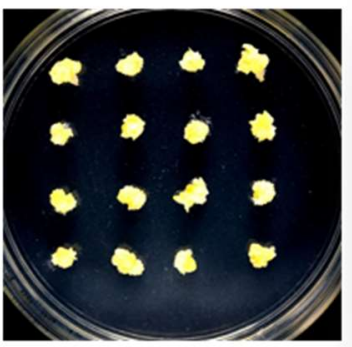

C

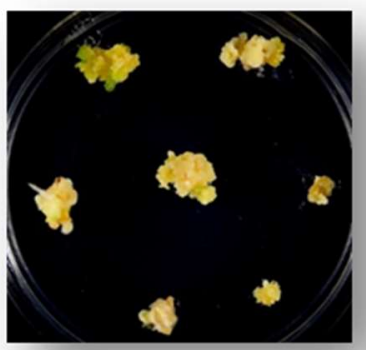

$\mathrm{D}$

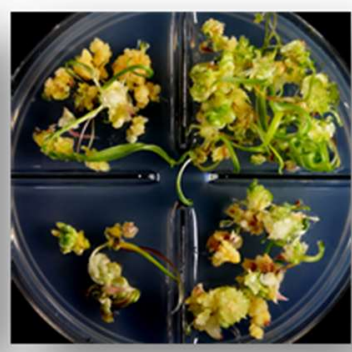

$\mathrm{E}$

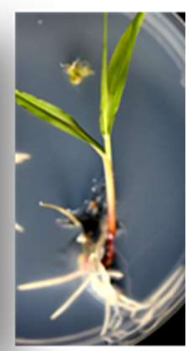


1 Figure 4. Schematic representation of an auto-excision construct design used for testing

2 elimination of a morphogenic gene and a marker gene using heat shock promoter driving Cre

3 expression for controlled gene excision. A) Construct design depicting the order of cassettes

4 including morphogenic genes, Hsp 17.7pro driving Cre expression, and the selectable marker

5 (HRA or NPTII) flanked by directly oriented loxP sites (a) which will be excised upon Cre

6 expression. B) Following excision, the DNA piece containing the ZS-GREEN expression

7 cassette is left in the T0 event for visual confirmation of excision. Refer to Table S-1 for

8 description of construct components used in T-DNA construction.

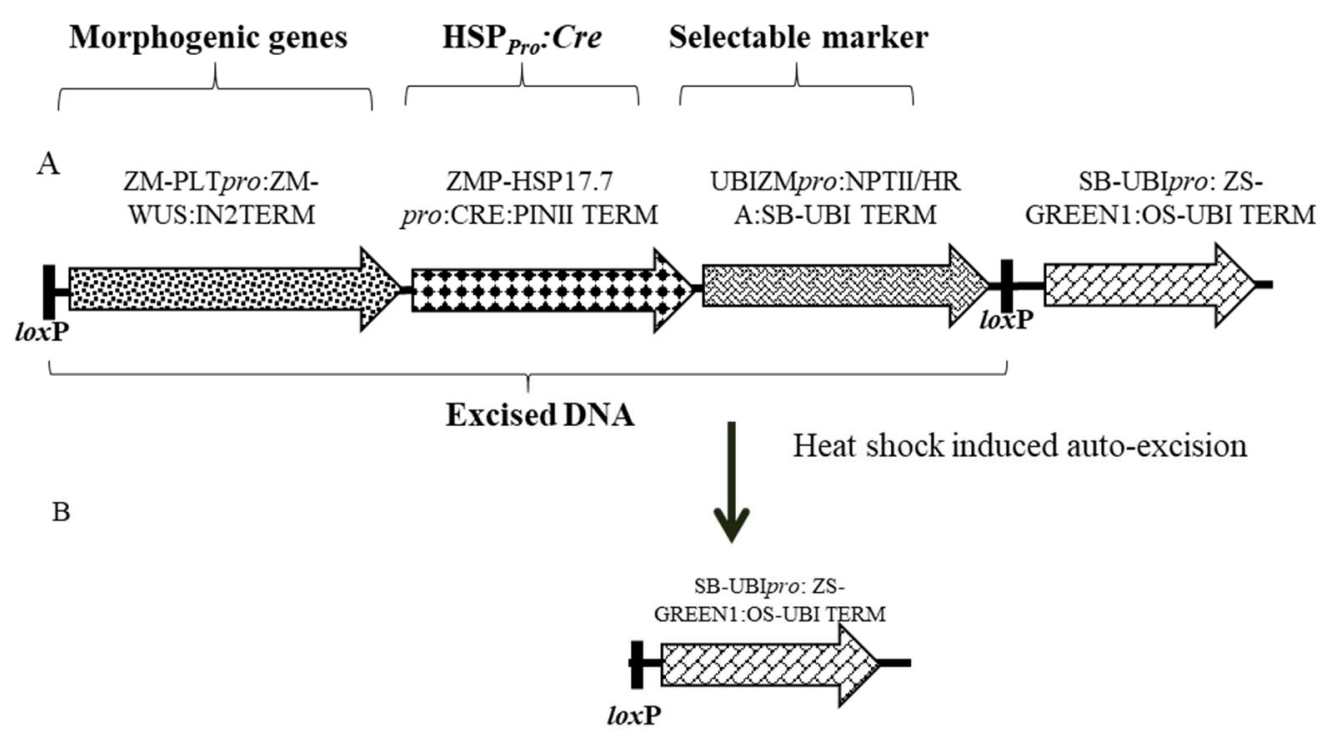


1 Table S-1. Construct components used in T-DNA construction.

\begin{tabular}{|c|c|c|c|}
\hline Component type & Label & Description & References \\
\hline \multirow[t]{4}{*}{ Promoters } & $S b-A l_{\text {pro }}$ & $\begin{array}{l}\text { The sorghum ALS } \\
\text { promoter }\end{array}$ & $\begin{array}{l}\text { SB-ALS promoter and 5'UTR, } \\
\text { DOE-JGI Sbi v3.1, SBChr04, } \\
\text { bases } 49239164-49240031 . \\
\text { DOE-JGI Sbi v3.1 corresponds } \\
\text { to Sorghum bicolor BTx623 } \\
\text { assembly v3.0.1 and gene } \\
\text { annotation v3.1 available from } \\
\text { phytozome } \\
\text { (http://phytozome.jgi.doe.gov/) } \\
\text {. Chromosome } 4 \text { of Sbi v3.1 is } \\
\text { registered as NCBI accessions } \\
\text { NC_012873.2 and } \\
\text { CM000763.3 }\end{array}$ \\
\hline & Pltppro & $\begin{array}{l}\text { Maize phospholipid } \\
\text { transferase promoter }\end{array}$ & $\begin{array}{l}\text { See GenBank sequence } \\
\text { (MN380778) }\end{array}$ \\
\hline & Axig1 $1_{\text {pro }}$ & $\begin{array}{l}\text { The maize Axig1 } \\
\text { promoter }\end{array}$ & (Garnaat et al., 2002) \\
\hline & Sb-Ubipro & $\begin{array}{l}\text { The sorghum Ubiquitin } \\
\text { promoter }\end{array}$ & (Shane, 2007) \\
\hline \multirow[t]{5}{*}{ 3' Sequences } & $\operatorname{In} 2-2$ & $\begin{array}{l}\text { The maize IN2-2 } \\
\text { terminator }\end{array}$ & (Hershey and Stoner, 1991) \\
\hline & PINII & $\begin{array}{l}\text { The potato proteinase } \\
\text { inhibitor II (pinII) } \\
\text { 3'sequence }\end{array}$ & (An et al., 1989) \\
\hline & Os-Ubi 3' & $\begin{array}{l}\text { The rice Ubiquitin } \\
\text { terminator }\end{array}$ & $\begin{array}{l}\text { Terminator region of the rice } \\
\text { Ubiquitin (Os06g46770.1), } \\
\text { unpublished }\end{array}$ \\
\hline & Sb-Ubi 3' & $\begin{array}{l}\text { The sorghum Ubiquitin } \\
\text { terminator }\end{array}$ & (Shane, 2007) \\
\hline & $O s-T 283^{\prime}$ & $\begin{array}{l}\text { The T28 3' regulatory } \\
\text { sequence from Oryza } \\
\text { sativa }\end{array}$ & (Bhyri et al., 2014) \\
\hline Marker genes & NPTII & $\begin{array}{l}\text { Maize codon- } \\
\text { optimized Neomycin } \\
\text { Phosphotransferase II }\end{array}$ & $\begin{array}{l}\text { Previously unpublished } \\
\text { Corteva Agriscience sequence }\end{array}$ \\
\hline
\end{tabular}




\begin{tabular}{|c|c|c|c|}
\hline & $H R A$ & $\begin{array}{l}\text { The maize ALS double } \\
\text { mutant gene conferring } \\
\text { herbicide resistance }\end{array}$ & (Green et al., 2009) \\
\hline & $\begin{array}{l}Z s- \\
Y E L L O W\end{array}$ & $\begin{array}{l}\text { The Zs-Yellow1 N1 } \\
\text { gene encoding a } \\
\text { yellow fluorescent } \\
\text { protein from Zoanthus } \\
s p\end{array}$ & (Matz et al., 1999) \\
\hline \multirow[t]{2}{*}{$\begin{array}{l}\text { Maize morphogenic } \\
\text { genes }\end{array}$} & Zm-Wus2 & $\begin{array}{l}\text { The maize Wuschel2 } \\
\text { (Wus2) gene }\end{array}$ & (Lowe et al., 2007) \\
\hline & $\mathrm{Zm-Bbm}$ & $\begin{array}{l}\text { The maize Baby boom } \\
\text { gene }(\mathrm{Bbm})\end{array}$ & (Gordon-Kamm et al., 2005) \\
\hline $\begin{array}{l}\text { Recombinase } \\
\text { Expression } \\
\text { Cassettes }\end{array}$ & Cre & $\begin{array}{l}\text { A maize-optimized } \\
\text { Cre recombinase gene } \\
\text { (originally from the P1 } \\
\text { bacteriophage), with an } \\
\text { inserted potato LS1 } \\
\text { intron }\end{array}$ & (Odell et al., 1990) \\
\hline $\begin{array}{l}\text { Recombinase } \\
\text { Target Sites }\end{array}$ & lox $\mathrm{P}$ & $\begin{array}{l}\text { The recombinase target } \\
\text { site for the Cre } \\
\text { recombinase from } E \text {. } \\
\text { coli }\end{array}$ & (Odell et al., 1990) \\
\hline
\end{tabular}

